\title{
Extracellular enzyme production and enterotoxigenic gene profiles of Bacillus cereus and Bacillus thuringiensis strains isolated from cheese in Turkey
}

\author{
Celenk Molva ${ }^{\mathrm{a}, *}$, Mert Sudagidan $^{\mathrm{b}}$, Burcu Okuklu $^{\mathrm{a}}$ \\ a Department of Food Engineering Izmir Institute of Technology, Gulbahce Campus, Urla 35430 Izmir, Turkey \\ ${ }^{\mathrm{b}}$ Biotechnology and Bioengineering Central Research Lab., Izmir Institute of Technology, Gulbahce Campus, Urla 35430 Izmir, Turkey
}

\section{A R T I C L E I N F O}

\section{Article history:}

Received 28 April 2008

Received in revised form 14 October 2008

Accepted 30 October 2008

\section{Keywords:}

Bacillus cereus

Bacillus thuringiensis

Cheese

Enterotoxin genes

\begin{abstract}
A B S T R A C T
The aim of the present study was to investigate the biochemical characteristics, extracellular enzyme production and enterotoxigenic genes contents of 6 Bacillus cereus and 22 Bacillus thuringiensis strains, isolated from 100 cheese samples in Turkey. Crystal morphologies of $B$. thuringiensis strains were found either spherical $(n=12)$ or spherical and irregular-shaped $(n=10)$ by phase contrast microscopy. B. cereus and $B$. thuringiensis strains were found to produce extracellular enzymes, respectively: gelatinase (83\% and $91 \%$ ), DNase ( $83 \%$ and $77 \%$ ), lecithinase ( $83 \%$ and $95 \%$ ), protease on skim milk agar (100\% and $100 \%)$, protease on milk agar (100\% and $91 \%)$, protease on casein agar ( $83 \%$ and $77 \%)$, xylanase (100\% and $45 \%$ ), and cellulase (0\% and $41 \%$ ), and amylase ( $83 \%$ and $27 \%$ ). All of the strains, except for Bt-D1, hydrolyzed Tween 20 (96\%), but not Tween 80 or tributyrin. Pectinolytic activity was obtained to be the least frequent (4\%). PCR analysis showed that all strains contained nheA, nheB, nheC and hblD genes. The $h b l A$ and $h b l C$ genes were present in 2 and 4 of $B$. thuringiensis strains, respectively. The bceT gene was detected in $1 \mathrm{~B}$. cereus and $9 \mathrm{~B}$. thuringiensis strains. The entFM gene was detected more frequently in $B$. thuringiensis (82\%) than in B. cereus strains (50\%). To our knowledge, this is the first report about the isolation and identification of enterotoxigenic $B$. cereus and $B$. thuringiensis strains from cheese samples in Turkey.
\end{abstract}

(c) 2008 Elsevier Ltd. All rights reserved.

\section{Introduction}

Bacillus cereus is considered to be a common food pathogen and Bacillus thuringiensis is distinguishable from this organism by the production of insecticidal crystal proteins ( $\delta$-endotoxins) inside the cell during sporulation (Höfte \& Whiteley, 1989). These two species are genetically similar and plasmids encoding for insecticidal crystals can be transferred to $B$. cereus, making the $B$. cereus a crystal-producing B. thuringiensis (Gonzáles, Brown, \& Calton, 1982). Therefore, they can be considered as one species on the basis of genetic evidence (Chen \& Tsen, 2002).

In dairy products, the presence of Bacillus spp. is inevitable and the spore-formation of this organism allows it to easily survive after pasteurization (Christiansson, Bertilsson, \& Svensson, 1999). The growth of $B$. cereus spoils the quality of dairy products due to the production of protease, lipase and phospholipase, and these in turn, causes some defects such as off-flavours, sweet curdling and bitty cream (Davies \& Wilkinson, 1973; Meer, Baker, Bodyfelt, \& Griffiths, 1991). Therefore, in milk and dairy products, it decomposes casein into peptides and amino acids, and milk fat into free fatty acids, thus degrading the quality of milk products and short-

\footnotetext{
* Corresponding author. Tel.: +90 2327506227; fax: +90 2327506196.

E-mail address: celenkcinar@iyte.edu.tr (C. Molva).
}

ening their shelf life (Torkar \& Matijašić, 2003). The occurrence of $B$. cereus as a contaminant of cheese was previously reported (Helmy, El-Bakey, \& Mohamed, 1984; Iurlina, Saiz, Fuselli, \& Fritz, 2006; Tham, Hadju, \& Danielsson-Tham, 1990). Although B. thuringiensis has been isolated from creamery silo milk (Phillips \& Griffiths, 1986), pasta, bread, milk (Damgaard, Larsen, Hansen, Bresciani, \& Jørgensen, 1996), and ready-to-eat food (Rosenquist, Smidt, Andersen, Jensen, \& Wilcks, 2005), no information about the prevalence of $B$. thuringiensis in cheese has been previously published.

B. cereus produces several toxins, including emetic toxin and diarrhoeal enterotoxins. Hemolysin $\mathrm{BL}(\mathrm{Hbl})$, nonhemolytic enterotoxin (Nhe) and cytotoxin $\mathrm{K}$ (CytK) proteins are considered as the primary virulence factors in B. cereus diarrhea (Granum, O'Sullivan \& Lund, 1999; Lund, Debuyser, \& Granum, 2000) and the other toxins enterotoxin FM (EntFM), enterotoxin T (BceT) or haemolysin II (HlyII) are regarded as three possible enterotoxins (Dohmae et al., 2008). HBL complex is composed of three proteins, $B, L_{1}$ and $L_{2}$ (Beecher \& Wong, 1994; Beecher \& Wong, 1997) transcribed from the genes $h b l C$ (encoding $\mathrm{L}_{2}$ ), $h b l D$ (encoding $\mathrm{L}_{1}$ ), and $h b l A$ (encoding B) (Heinrichs, Beecher, MacMillan, \& Zilinskas, 1993; Ryan, Macmillan, \& Zilinskas, 1997). NHE complex is also composed of three proteins, NheA, NheB and NheC encoded by the three genes $n h e A$, nheB and nheC, respectively (Granum, O'Sullivan, \& Lund, 
1999). Also, B. thuringiensis strains, including the strains used in commercial insecticides are reported to encode and produce diarrhoeal enterotoxins similar to those produced by B. cereus (Damgaard et al., 1996; Damgaard et al., 1997; Jensen et al., 2002a; Perani, Bishop, \& Vaid, 1998).

This is the first study to determine the presence of $B$. cereus/B. thuringiensis strains in Turkish cheese and their enterotoxin gene content. Our purpose was (i) to isolate B. cereus/B. thuringiensis from cheese samples collected from different regions of Turkey, (ii) to identify the isolates using biochemical tests (iii) to determine the extracellular enzyme productions and (iv) to search the presence of $h b l A, h b l C$ and $h b l D$ genes of the HBL complex; the nheA, nheB and nheC genes of the NHE complex; bceT and entFM genes.

\section{Materials and methods}

\subsection{Isolation of the strains}

A total of 100 cheese samples were collected from different regions of Turkey (Table 1 ). First, ten-fold $10 \mathrm{~g}$ of each sample was added into $90 \mathrm{ml} 0.1 \%\left(\mathrm{wv}^{-1}\right)$ peptone water. The samples were mixed well, homogenized by vigorous vortexing at room temperature for $3 \mathrm{~min}$. Ten-fold dilution was prepared in $20 \%$ $\left(\mathrm{vv}^{-1}\right)$ glycerol-peptone water. A $50 \mu \mathrm{l}$ aliquot from this dilution was inoculated into $5 \mathrm{ml}$ Nutrient Broth (NB) (Applichem) and incubated at $37^{\circ} \mathrm{C}$ for $18 \mathrm{~h}$ with shaking at $150 \mathrm{rpm}$. The tubes were pasteurized at $80^{\circ} \mathrm{C}$ for $10 \mathrm{~min}$ to eliminate non-sporulating bacteria. The suspension was streaked onto chromogenic $B$. cereus agar (BCA) supplemented with chromogenic $B$. cereus selective supplement (Oxoid). The plates were incubated at $37^{\circ} \mathrm{C}$ overnight and blue/green colonies were subcultured on chromogenic BCA until obtaining a pure culture. After identification by biochemical tests (Gram staining and catalase test), the isolated strains were stored in sterile NB containing $20 \%\left(\mathrm{vv}^{-1}\right)$ glycerol at $-80^{\circ} \mathrm{C}$.

\subsection{Phase contrast microscopy}

The strains belonging to $B$. cereus/B. thuringiensis group were streaked on T3 medium (tryptone $3 \mathrm{~g} \mathrm{l}^{-1}$, tryptose $2 \mathrm{~g} \mathrm{l}^{-1}$, yeast extract $1.5 \mathrm{~g} \mathrm{l}^{-1}$, sodium phosphate $0.05 \mathrm{M}$ [pH 6.8], $\mathrm{MnCl} 0.005 \mathrm{~g} \mathrm{l}^{-1}$ and agar $15 \mathrm{~g} \mathrm{l}^{-1}$ ) (Travers, Martin, \& Reichelderfer, 1987) and examined by a phase contrast microscope (Olympus CX31) and image analyzing system (Olympus DP-2 BSW) in order to investigate the presence of crystal proteins after 24 - and 48-h incubations at $37^{\circ} \mathrm{C}$. Those producing parasporal inclusions were assigned to $B$. thuringiensis, while the parasporal inclusion-lacking isolates were classified as B. cereus (Ohba \& Aratake, 1994).

Table 1

Distribution of $B$. cereus $(\mathrm{Bc})$ and $B$. thuringiensis (Bt) strains and the sampling regions in Turkey.

\begin{tabular}{lclll}
\hline $\begin{array}{l}\text { Sampling } \\
\text { region }\end{array}$ & $\begin{array}{l}\text { No. of } \\
\text { samples }\end{array}$ & $\begin{array}{l}\text { No. of samples } \\
\text { containing Bc/Bt }\end{array}$ & $\begin{array}{l}\text { No. of isolated } \\
\text { Bc strains }\end{array}$ & $\begin{array}{l}\text { No. of isolated } \\
\text { Bt strains }\end{array}$ \\
\hline Nevsehir & 35 & 1 & - & 3 \\
Edirne & 16 & 1 & - & 2 \\
Izmir & 14 & 4 & 1 & 8 \\
Manisa & 14 & 1 & - & 2 \\
Tekirdag & 11 & 3 & 4 & 5 \\
Ardahan & 4 & - & - & - \\
Erzincan & 2 & 1 & 1 & 1 \\
Konya & 1 & - & - & - \\
Tunceli & 1 & - & - & - \\
Mugla & 1 & 1 & - & 1 \\
Kutahya & 1 & - & - & - \\
Total & 100 & 12 & 6 & 22 \\
\hline
\end{tabular}

\subsection{Biochemical characteristics of the strains}

Hemolysis and motility tests were performed according to the methods by Ehling-Schulz et al. (2005) and Guttmann and Ellar (2000), respectively. Utilization of 19 carbohydrates and growth of the strains in $2.5 \%, 5 \%, 7.5 \%$ and $10 \%\left(\mathrm{wv}^{-1}\right) \mathrm{NaCl}$ in $\mathrm{NB}$ was analyzed in 96 -well plates.

\subsection{Extracellular enzyme production}

The strains were screened for extracellular enzyme productions at $37^{\circ} \mathrm{C}$ according to the protocols described by the following studies: gelatin liquefaction (Harrigan, 1998), lecithinase activity (Guttmann \& Ellar, 2000), xylanase, amylase and cellulase production (Bragger, Daniel, Coolber, \& Morgan, 1989), and pectinolytic activity on pectinase I medium (yeast extract $1 \mathrm{~g} \mathrm{l}^{-1},\left(\mathrm{NH}_{4}\right)_{2} \mathrm{SO}_{4} 2 \mathrm{~g} \mathrm{l}^{-1}$, $\mathrm{Na}_{2} \mathrm{HPO}_{4} 6 \mathrm{~g} \mathrm{l}^{-1} \mathrm{~K}_{2} \mathrm{PO}_{4} 3 \mathrm{~g} \mathrm{l}^{-1}$, polygalactronic acid $5 \mathrm{~g} \mathrm{l}^{-1}$, agar $15 \mathrm{~g} \mathrm{l}^{-1}$ ) and pectinase II medium (yeast extract $1 \mathrm{~g} \mathrm{l}^{-1},\left(\mathrm{NH}_{4}\right)_{2} \mathrm{SO}_{4}$ $2 \mathrm{~g} \mathrm{l}^{-1}, \mathrm{Na}_{2} \mathrm{HPO}_{4} 6 \mathrm{~g} \mathrm{l}^{-1}, \mathrm{KH}_{2} \mathrm{PO}_{4} 3 \mathrm{~g} \mathrm{l}^{-1}$, pectin from citrus peel $5 \mathrm{~g} \mathrm{l}^{-1}$, agar $15 \mathrm{~g} \mathrm{l}^{-1}$ ) (Kobayashi et al., 1999). Lipolytic activity of the strains was determined using Tween 20, Tween 80 (Haba et al., 2000) and tributyrin agar medium (Merck). Protease screening was performed on skim milk agar (Priest, Goodfellow, \& Todd, 1988), milk agar (Nutrient Agar (NA) containing $10 \%\left(\mathrm{vv}^{-1}\right)$ UHT milk) and casein agar (casein $10 \mathrm{~g} \mathrm{l}^{-1}$, yeast extract $3 \mathrm{~g} \mathrm{l}^{-1}, \mathrm{NaCl}$ $5 \mathrm{~g} \mathrm{l}^{-1}$ and agar $20 \mathrm{~g} \mathrm{l}^{-1}, \mathrm{pH}$ 7.4). DNase production was examined on DNase agar media (Oxoid).

\subsection{Genomic DNA isolation}

Genomic DNA was extracted by first freezing and then boiling the cells (Bravo et al., 1998). Strains were grown at $37^{\circ} \mathrm{C}$ for $16 \mathrm{~h}$. A loopful of cells was scraped off from NA plate and resuspended in $150 \mu \mathrm{l}$ sterile water. After $20 \mathrm{~min}$ freezing at $-80^{\circ} \mathrm{C}$, the samples were boiled for $10 \mathrm{~min}$ to lyse the cells completely. Cell debris was removed by centrifugation $(11000 \mathrm{~g}, 10 \mathrm{~s})$. The supernatant containing genomic DNA was stored at $-20^{\circ} \mathrm{C}$.

\subsection{Examination of enterotoxin genes}

The strains were tested for the presence of enterotoxin genes (nheA, nheB, nheC, hblA, hblC, hblD, bceT and entFM). The primer sets used in this study are presented in Table 2. Each amplification process was performed in a $50 \mu \mathrm{l}$ reaction mixture containing $100 \mathrm{ng}$

Table 2

The primer sequences and amplicon sizes used in PCR analysis.

\begin{tabular}{|c|c|c|c|}
\hline Gene & $\begin{array}{l}\text { Primer sequences }\left(5^{\prime} \rightarrow 3^{\prime}\right) \\
\text { F: forward; R: reverse }\end{array}$ & $\begin{array}{l}\text { Amplicon } \\
\text { size (bp) }\end{array}$ & Reference \\
\hline bcet & $\begin{array}{l}\text { F-TTACATTACCAGGACGTGCTT } \\
\text { R-TGTTTGTGATTGTAATTCAGG }\end{array}$ & 428 & Agata et al. (1995) \\
\hline entFM & $\begin{array}{l}\text { F-ATGAAAAAAGTAATTTGCAGG } \\
\text { R-TTAGTATGCTTTTGTGTAACC }\end{array}$ & 1269 & $\begin{array}{l}\text { Asano, Nukumuzi, } \\
\text { Bando, Iizuka and } \\
\text { Yamamoto (1997) }\end{array}$ \\
\hline$h b l A$ & $\begin{array}{l}\text { F-GCTAATGTAGTTTCACCTGTAGCAAC } \\
\text { R-AATCATGCCACTGCGTGGACATATAA }\end{array}$ & 874 & $\begin{array}{l}\text { Mäntynen and } \\
\text { Lindström (1998) }\end{array}$ \\
\hline hblc & $\begin{array}{l}\text { F-CGAAAATTAGGTGCGCAATC } \\
\text { R-TAATATGCCTTGCGCAGTTG }\end{array}$ & 411 & $\begin{array}{l}\text { Moravek et al. } \\
(2004)\end{array}$ \\
\hline$h b l D$ & $\begin{array}{l}\text { F-AGGTCAACAGGCAACGATTC } \\
\text { R-CGAGAGTCCACCAACAACAG }\end{array}$ & 206 & $\begin{array}{l}\text { Moravek et al. } \\
\text { (2004) }\end{array}$ \\
\hline nheA & $\begin{array}{l}\text { F-ATTAAGGTAAATGCGATGAG } \\
\text { R-GCTTCAGTTTGTGATAACTT }\end{array}$ & 671 & $\begin{array}{l}\text { Jensen et al. } \\
\text { (2002b) }\end{array}$ \\
\hline nheB & $\begin{array}{l}\text { F-CTATCAGCACTTATGGCAG } \\
\text { R-ACTCCTAGCGGTGTTCC }\end{array}$ & 769 & $\begin{array}{l}\text { Granum et al. } \\
\text { (1999) }\end{array}$ \\
\hline nheC & $\begin{array}{l}\text { F-TGGATTCCAAGATGTAACG } \\
\text { R-ATTACGACTTCTGCTTGTGC }\end{array}$ & 683 & $\begin{array}{l}\text { Guinebretiére } \\
\text { et al. } \\
\text { (2002) }\end{array}$ \\
\hline
\end{tabular}


of genomic DNA as the template, $5 \mu$ l of $10 \times$ reaction buffer (100 mM Tris- $\mathrm{HCl}(\mathrm{pH} 8.8), 500 \mathrm{mM} \mathrm{KCl}, 0.8 \%\left(\mathrm{vv}^{-1}\right)$ Nonident P40 , and $1.5 \mathrm{mM} \mathrm{MgCl}_{2}$ ), $10 \mu \mathrm{M}$ of each of the primers, $0.2 \mathrm{mM}$ each of the four dNTPs (Fermentas) and $2 \mathrm{U}$ Taq DNA polymerase (Fermentas). The diarrhoeagenic strain of B. cereus (ATCC 14579) was used as a positive control. PCR products were analyzed in $1.5 \%$ $\left(\mathrm{wv}^{-1}\right)$ TAE agarose gels and all PCR experiments were performed twice for each strain.

\section{Results}

\subsection{Identification and phase contrast microscopy}

The prevalence of $B$. cereus/B. thuringiensis strains in the cheese samples is shown in Table 1 . In total, 100 cheese samples were analyzed and 12 of them were found to contain B. cereus/B. thuringiensis strains. Twenty-eight isolates with the typical phenotypic characteristics of $B$. cereus/B. thuringiensis on chromogenic BCA were isolated. All B. cereus/B. thuringiensis strains were found to produce spores after $24 \mathrm{~h}$ incubation and $22 / 28$ (79\%) strains of $B$. cereus/B. thuringiensis were assigned to $B$. thuringiensis due to the formation of crystal proteins by phase contrast microscopy (Fig. 1). Spherical crystals were found in 12 strains, while spherical and irregular-shaped crystals were found in the remaining $10 \mathrm{~B}$. thuringiensis strains.

\subsection{Biochemical characteristics}

In this study, 5 B. cereus and $21 B$. thuringiensis strains exhibited $\beta$-hemolysis, confirming the presence of a hemolytic enterotoxin. All $B$. cereus and $21 B$. thuringiensis strains were actively-motile after $72 \mathrm{~h}$ incubation. All strains produced acid from glucose, ribose and maltose; however, arabinose, mannitol, xylose, rhamnose, melebiose, raffinose, and sorbitol were not utilized by the strains. Acid production from other carbohydrates was variable (Table 3 ). In addition, all strains were able to grow in the presence of $2.5 \%$ and $5 \%\left(\mathrm{wv}^{-1}\right) \mathrm{NaCl}$.

\subsection{Extracellular enzyme production}

The most frequent extracellular enzyme activities were as follows for $B$. cereus/B. thuringiensis strains, respectively: gelatin

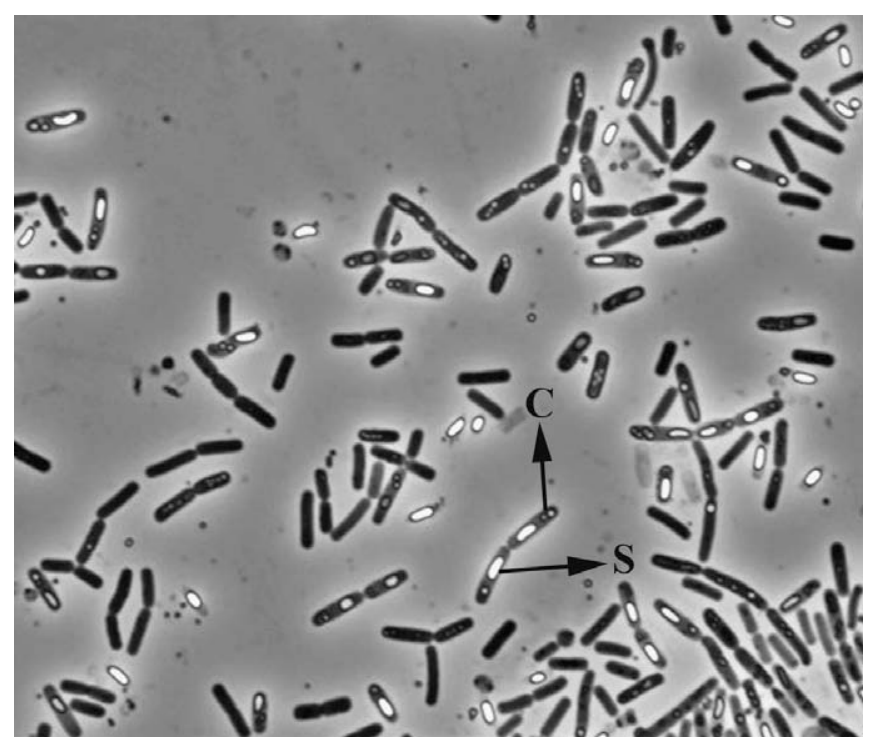

Fig. 1. Phase contrast microscope image of a 48-h sporulated culture of $B$. thuringiensis strain Bt-L11B. The arrowheads indicate S, spore and C, crystal. hydrolysis (83\% and 91\%), DNase (83\% and 77\%) and lecithinase production (83\% and $95 \%)$, protease on skim milk agar (100\% and $91 \%$ ), milk agar ( $83 \%$ and $77 \%$ ), and casein agar ( $83 \%$ and $77 \%$ ), amylase ( $83 \%$ and $27 \%$ ) and xylanase (100\% and $45 \%)$. All of the strains except Bt-D1 hydrolyzed Tween 20 (96\%), but not Tween 80 and tributyrin. Cellulase was only produced by $41 \%$ of $B$. thuringiensis strains. Pectinolytic activity was obtained to be the least frequent activity; which was only produced by the strain Bt-L11C on pectinase II medium (Table 3 ).

According to the production of extracellular enzymes, 13 different patterns were observed among $6 \mathrm{~B}$. cereus and $22 \mathrm{~B}$. thuringiensis. $B$. cereus/B. thuringiensis strains could be divided into two and twelve groups, respectively (Table 3 ). Among $B$. cereus strains, most strains $(n=5)$ belonged to group I, and one strain to group II. According to the presence of extracellular enzymes in B. thuringiensis, identical strains were obtained among groups XIII $(n=4)$, IV $(n=4)$, XII $(n=3)$, III $(n=2)$ and VI $(n=2)$.

\subsection{Examination of enterotoxin genes}

The distribution of enterotoxin genes among strains is shown in Fig. 2. It was found that all $B$. cereus/B. thuringiensis strains contained nheA, nheB, nheC and hblD genes. B. cereus strains were devoid of $h b l A$ and $h b l C$ genes. However, $2 B$. thuringiensis strains contained $h b l A$ and $4 B$. thuringiensis strains had $h b l C$. The bceT gene was detected only in $1 \mathrm{~B}$. cereus and $9 \mathrm{~B}$. thuringiensis strains. Interestingly, the entFM gene was detected more frequently in $B$. thuringiensis (82\%) than in B. cereus (50\%). Based on the results of the PCR, $B$. cereus/B. thuringiensis strains were divided into three and seven groups. Also, the strains which were identical in enzyme patterns were not identical at the level of enterotoxin genes (Table 3 ).

\section{Discussion}

B. cereus/B. thuringiensis strains, isolated from different Turkish cheese samples, were well characterized in this study on the basis of a number of biochemical and genotypic characteristics. B. cereus/B. thuringiensis strains were detected in $12 \%$ of the samples. The fact that cheese is a good source for the isolation of $B$. cereus (Cosentino, Mulargia, Pisano, Tuveri, \& Palmas, 1997; Iurlina et al., 2006; Rukure \& Bester, 2001), but there has been no information about the isolation of $B$. thuringiensis strains from cheese. Rukure and Bester (2001) reported that B. cereus spores can survive, germinate and grow into vegetative cells during the early stages of cheese manufacturing process, but not during the final stages of the process or ripening. Ahmed, Moustafa, and Marth (1983) examined the presence of $B$. cereus in 400 milk and dairy products and they isolated $B$. cereus strains from $9 \%, 14 \%, 35 \%$, and $48 \%$ of raw milk, cheese, pasteurized milk and ice cream samples, respectively. The low incidence of $B$. cereus/B. thuringiensis strains can be explained due to the textural characteristics of Turkish white cheese. It has a soft texture when fresh, after ripening it becomes semi-hard or semi-soft (Öner, Karahan, \& Aloğlu, 2006). In fact, the type of cheese samples affects the potential growth of $B$. cereus. In soft cheeses (refrigerated below $8{ }^{\circ} \mathrm{C}$ ), the incidence of $B$. cereus was $4 \%$ (Tham et al., 1990), while this ratio was $50 \%$ in hard cheeses (Helmy et al., 1984).

Most of the isolated B. cereus/B. thuringiensis strains were found to produce extracellular enzymes: lecithinase, gelatinase, lipase and protease. These enzymatic activities are very important for dairy industry. Lipolytic activity was shown as the reason for both rancid and fruity off-flavours in milk products (Downey, 1980; Johnston \& Bruce, 1982). In addition, proteolytic activity is related to spoilage of UHT milk, sweet curdling of milk, bitterness, other off-flavours in cheese, and textural or body defects in cultured dairy products (Cousin, 1982; Dairy Research Foundation, 1986). 
Table 3

Biochemical characteristics, extracellular enzyme production and enterotoxin gene contents of B. cereus (Bc) and B. thuringiensis (Bt) strains.

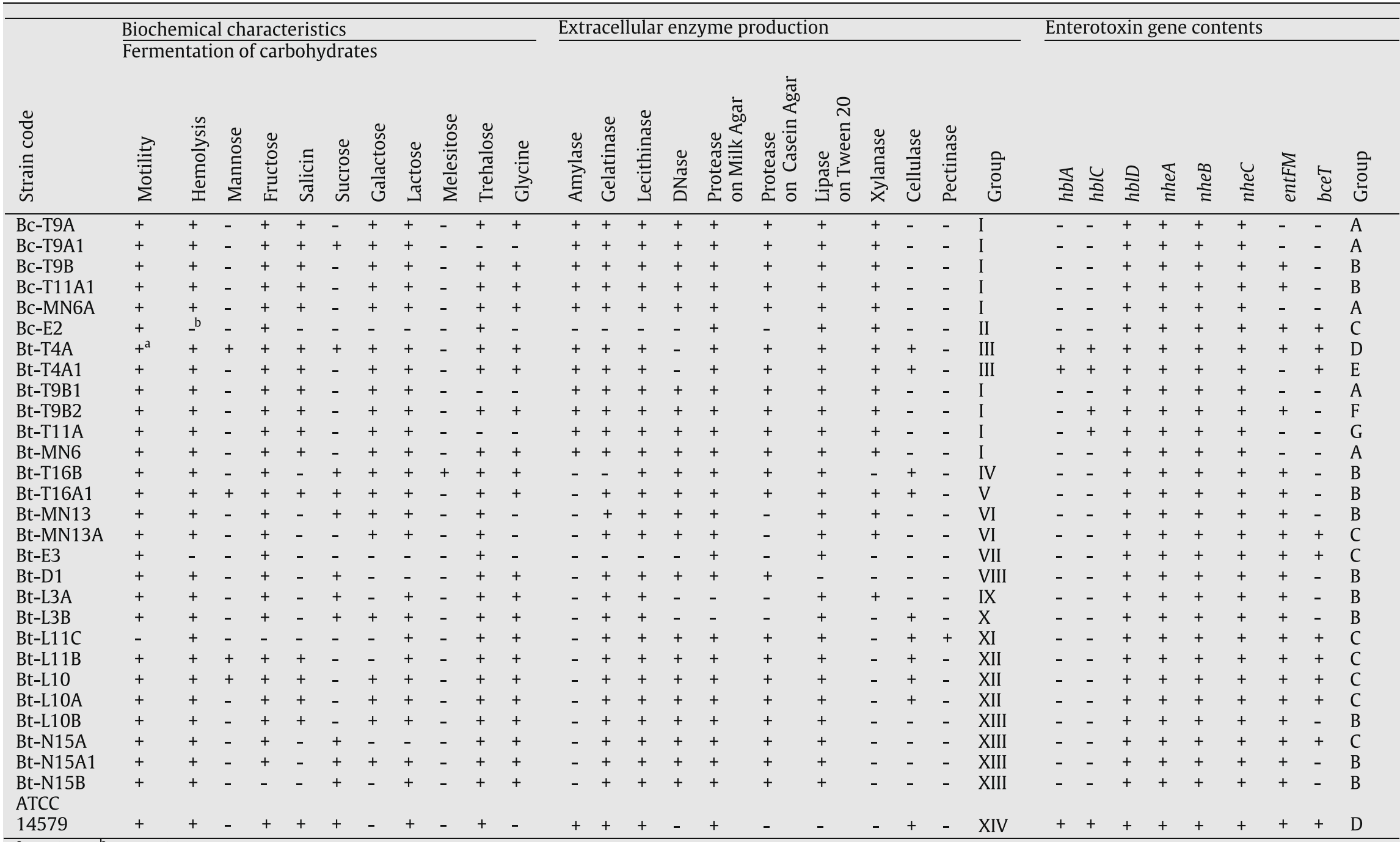

${ }^{\mathrm{a}}$ Positive, Negative 


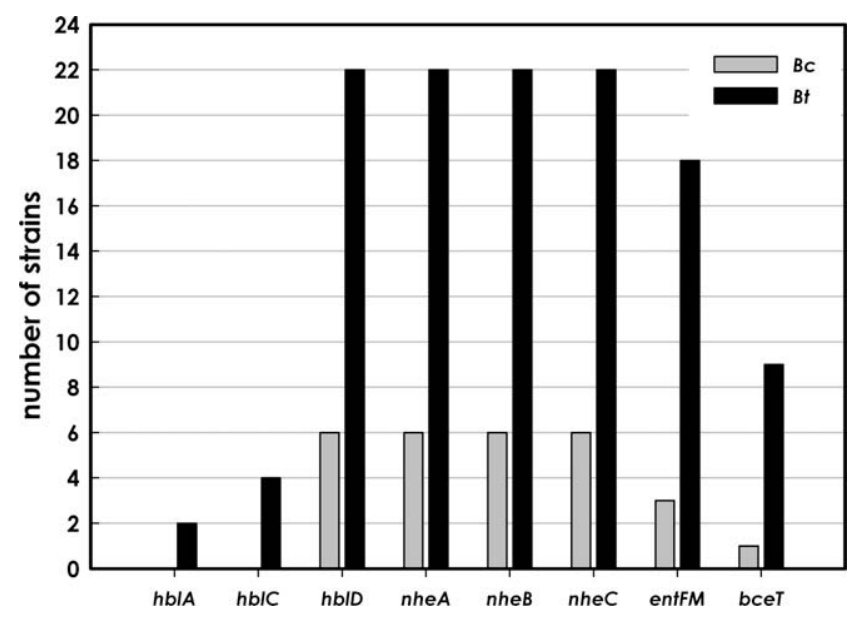

Fig. 2. Distribution of enterotoxin genes among B. cereus and B. thuringiensis strains.

It is known that $B$. cereus strains isolated from dairy products adapt to environmental conditions, especially for the fermentation of lactose which is an uncommon carbon source. In this study, $83 \%$ B. cereus and $86 \%$ B. thuringiensis strains were able to ferment lactose. Similarly, te Giffel, Beumer, Granum, and Rombouts (1997) observed that $20 \%$ of 134 B. cereus strains isolated from pasteurized milk samples could ferment lactose, whereas this ratio was less than $1 \%$ in the strains isolated from non-dairy products (te Giffel, Beumer, Leijendekkers, \& Rombouts, 1996).

The presence of diarrhoeal enterotoxin genes in the isolated strains was screened by PCR (Gaviria Rivera, Granum, \& Priest, 2000; Hansen \& Hendriksen, 2001; Tsen, Chen, Hsieh, Sheu, \& Chen, 2000; Zahner et al., 2005). In the detection of enterotoxin genes, all strains were found to carry the three nhe genes. Recently, it has been shown that almost all $B$. cereus/B. thuringiensis strains contain nhe genes (Beecher, 2001; Gaviria Rivera et al., 2000; Guinebretiére, Broussolle \& Nguyen-The, 2002; Hansen \& Hendriksen, 2001). In our study, all strains were also found to contain $\mathrm{hblD}$ gene. In another study, Hansen and Hendriksen (2001) reported that $95 \%$ B. thuringiensis strains and $64 \%$ B. cereus strains contained this gene. B. cereus strains did not contain the $h b l A$ and $h b l C$ genes, while the prevalence of these two $\mathrm{hbl}$ genes was low in $B$. thuringiensis strains, only $2(9 \%)$ and $4(18 \%)$ strains were positive for $h b l A$ and $h b l C$ genes, respectively. Mäntynen and Lindström (1998) detected $\mathrm{hblA}$ gene in $52 \%$ of their B. cereus strains and only in $1 / 41$ of their B. thuringiensis strains. On the other hand, Hansen and Hendriksen (2001) reported the high prevalence of the hblA gene in 31/ $41 \mathrm{~B}$. thuringiensis and in $13 / 22 \mathrm{~B}$. cereus strains. They also showed that $40 \mathrm{~B}$. thuringiensis (98\%) and $16 \mathrm{~B}$. cereus (73\%) strains contained $h b l C$.

The presence of bceT gene was relatively rare in our B. cereus (17\%) and B. thuringiensis (41\%) strains and this situation was also observed in the other studies (Agata, Ohta, Arakawa, \& Mori, 1995; Granum et al., 1996; te Giffel et al., 1997; Hsieh, Sheu, Chen, \& Tsen, 1999). On the other hand, Zahner et al. (2005) reported that bceT was found in $86 \%$ of $B$. thuringiensis strains and in $78 \%$ of $B$. cereus strains. The entFM gene was detected at a significantly higher proportion among $B$. thuringiensis strains $(82 \%)$ than detected in the $B$. cereus strains (50\%). In a previous study, Hsieh et al. (1999) found the entFM gene in $93 \%$ of $B$. cereus strains and in $78 \%$ of $B$. thuringiensis strains.

PCR analysis is used as a routine detection method for the enterotoxin genes in a large variety of strains (Svensson et al., 2007). Lower sensitivity levels are observed due to high degree of molecular heterogeneity in genes of $\mathrm{Hbl}$ and Nhe components leading to false negative PCR results (Schoeni \& Wong, 1999;
Guinebretiére et al., 2002). PCR is a specific and accurate method, but it only identifies potential HBL producing bacteria that may not always correlate to the expression of toxin components ( $\mathrm{Ku}-$ mar, Muralli, \& Batra, 2008). Therefore, the use of combined methods such as immunology and PCR may be necessary to detect the presence of toxin genes (Svensson et al., 2007; Ouoba, Thorsen, \& Varnam, 2008).

The majority of our strains exhibited hemolysis and these results also confirmed the presence of a hemolytic enterotoxin. It is interesting to note that 26 strains that were negative for $h b l A$ gene also showed hemolytic activity on blood agar. A similar result was reported by Gray, Banada, O'Neal and Bhunia (2005). They could not find the hblA gene in three strains which also showed hemolytic activity. They suggested that the PCR primers were targeted only toward the B component of the hemolytic gene. Although this component was not present in these strains, two L components of HBL might be found to exhibit hemolysis (Beecher, Schoeni, \& Wong, 1995; Beecher \& Wong, 1997). We could not find any correlation between the $h b l$ genes and hemolysis. Ouoba et al. (2008) indicated that the production of toxins is not necessarily related to hemolytic activity. Only two strains were found to contain the three genes for the HBL complex. The other strains showing hemolysis contained one or two of $h b l$ genes. Two strains which did not show hemolysis were found to contain the hblD gene by PCR.

In conclusion, $B$. cereus/B. thuringiensis strains isolated from cheese samples should be regarded as potential enterotoxin producers according to PCR results. Therefore, much more detailed research on the phenotypic expression of enterotoxins should be performed. In the light of this study, it is important to prevent the contamination of cheese by $B$. cereus/B. thuringiensis strains. Moreover, new attempts should be undertaken to eliminate these organisms during cheese manufacturing for food safety and quality.

\section{Acknowledgements}

The authors wish to thank Assoc. Prof. Dr. Ali Aydin (Istanbul University) for collecting the samples. Prof. Dr. Orhan Öztürk (Izmir Institute of Technology) is acknowledged for critical reading of the manuscript.

\section{References}

Agata, N., Ohta, M., Arakawa, Y., \& Mori, M. (1995). The bceT gene of Bacillus cereus encodes an enterotoxic protein. Microbiology, 141, 983-988.

Ahmed, A. A., Moustafa, M. K., \& Marth, E. H. (1983). Incidence of Bacillus cereus in milk and some milk products. Journal of Food Protection, 46, 126-128.

Asano, S. I., Nukumuzi, Y., Bando, H., Iizuka, T., \& Yamamoto, T. (1997). Cloning of novel enterotoxin genes from Bacillus cereus and Bacillus thuringiensis. Applied and Environmental Microbiology, 63, 1054-1057.

Beecher, D. J., \& Wong, A. C. L. (1994). Improved purification and characterization of hemolysin BL, a hemolytic dermonecrotic vascular permeability factor from Bacillus cereus. Infection and Immunity, 62, 980-986.

Beecher, D. J., Schoeni, J. L., \& Wong, A. C. L. (1995). Enterotoxin activity of hemolysin BL from Bacillus cereus. Infection and Immunity, 63, 4423-4428.

Beecher, D. J., \& Wong, A. C. L. (1997). Tripartite hemolysin BL from Bacillus cereus. Hemolytic analysis of component interactions and a model for its characteristics paradoxical zone phenomenon. The Journal of Biological Chemistry, 272, 233-239.

Beecher, D. J. (2001). The Bacillus cereus group. In M. Sussman (Ed.), Molecular medical microbiology (pp. 1161-1190). New York: Academic Press.

Bragger, J. M., Daniel, R. M., Coolber, T., \& Morgan, H. W. (1989). Very stable enzymes from extremely thermophilic archaebacteria and eubacteria. Applied Microbiology and Biotechnology, 31, 556-561.

Bravo, A., Sarabia, S., Lopez, L., Ontiveros, H., Abarca, C., Ortiz, A., et al. (1998). Characterization of cry genes in a Mexican Bacillus thuringiensis strain collection. Applied and Environmental Microbiology, 64, 4965-4972.

Chen, M. L., \& Tsen, H. Y. (2002). Discrimination of Bacillus cereus and Bacillus thuringiensis with $16 \mathrm{~S}$ rRNA and gyrB gene based PCR primers and sequencing of their annealing sites. Journal of Applied Microbiology, 92, 912-919.

Christiansson, A., Bertilsson, J., \& Svensson, B. (1999). Bacillus cereus spores in raw milk: factors affecting the contamination of milk during the grazing period. Journal of Dairy Science, 82, 305-314. 
Cosentino, S., Mulargia, A. F., Pisano, B., Tuveri, P., \& Palmas, F. (1997). Incidence and biochemical characteristics of Bacillus flora in Sardinian dairy products. International Journal of Food Microbiology, 38, 235-238.

Cousin, M. A. (1982). Presence and activity of psychotropic microorganisms in milk and dairy products. Journal of Food Protection, 45, 172-207.

Dairy Research Foundation (1986). The significance of psychotropic bacteria in milk and dairy products. Rosemont: Dairy Research Foundation.

Damgaard, P. H., Larsen, H. D., Hansen, B. M., Bresciani, J., \& Jørgensen, K. (1996). Enterotoxin-producing strains of Bacillus thuringiensis isolated from food. Letters in Applied Microbiology, 23, 146-150.

Damgaard, P. H., Granum, P. E., Bresciani, J., Torregrossa, M. V., Eilenberg, J., \& Valentino, L. (1997). Characterization of Bacillus thuringiensis isolated from infections in burn wounds. FEMS Immunology and Medical Microbiology, 18, 47-53.

Davies, F. L., \& Wilkinson, G. (1973). Bacillus cereus in milk and dairy products. In B. C. Hobbs \& J. H. B. Christian (Eds.), The microbiological safety of food (pp. 57-68). New York: Academic Press.

Dohmae, S., Okubo, T., Higuchi, W., Takano, T., Isobe, H., Baranovich, T., et al. (2008). Bacilus cereus nosocomical infection from reused towels in Japan. Journal of Hospital Infection, 69, 361-367.

Downey, W. K. (1980). Review of progress dairy science. flavour impairment from pre and postmanufacture lipolysis in milk and dairy products. Journal of Dairy Research, 47, 237-252.

Ehling-Schulz, M., Svensson, B., Guinebretiére, M., Lindbäck, T., Andersson, M., Schulz, A., et al. (2005). Emetic toxin formation of Bacillus cereus is restricted to a single evolutinary lineage of closely related strains. Microbiology, 151, 183-197.

Gaviria Rivera, A. M., Granum, P. E., \& Priest, F. G. (2000). Common occurrence of enterotoxin genes and enterotoxicity in Bacillus thuringiensis. FEMS Microbiology Letters, 190, 151-155.

Gonzáles, J. M., Brown, B. J., \& Calton, B. C. (1982). Transfer of Bacillus thuringiensis plasmids coding for endotoxins among strains of $B$. thuringiensis and $B$. cereus. Proceedings of the National Academy of Sciences of the United States of America, 79, 6951-6955.

Granum, P. E., Andersson, A., Gayther, C., te Giffel, M., Larse, H., Lund, T., et al. (1996). Evidence for a further enterotoxin complex produced by Bacillus cereus. FEMS Microbiology Letters, 141, 145-149.

Granum, P. E., O'Sullivan, K., \& Lund, T. (1999). The sequence of the non-haemolytic enterotoxin operon from Bacillus cereus. FEMS Microbiology Letters, 177, 225-229.

Gray, K. M., Banada, P. P., O’Neal, E., \& Bhunia, A. K. (2005). Rapid Ped-2E9 cell-based cytotoxicity analysis and genotyping of Bacillus species. Journal of Clinical Microbiology, 43, 5865-5872.

Guinebretiére, M.-H., Broussolle, V., \& Nguyen-The, C. (2002). Enterotoxigenic profiles of food-poisoning and food-borne Bacillus cereus strains. Applied and Environmental Microbiology, 40, 3053-3056.

Guttmann, D. M., \& Ellar, D. J. (2000). Phenotypic and genotypic characterization of 23 strains from the Bacillus cereus complex for a selection of known and putative Bacillus thuringiensis virulence factors. FEMS Microbiology Letters, 188, 7-13.

Haba, E., Bresco, O., Ferrer, C., Marques, A., Basquets, M., \& Manresa, A. (2000). Isolation of lipase secreting bacteria by deploying used frying oil as selective substrate. Enzyme and Microbial Technology, 26, 40-44.

Hansen, B. M., \& Hendriksen, N. B. (2001). Detection of enterotoxic Bacillus cereus and Bacillus thuringiensis strains by PCR analysis. Applied and Environmental Microbiology, 67, 185-189.

Harrigan, W. F. (1998). Laboratory methods in food microbiology. London: Academic Press (pp. 100-101).

Heinrichs, J. H., Beecher, D. J., MacMillan, J. D., \& Zilinskas, B. A. (1993). Molecular cloning and characterization of the hblA gene encoding the $\mathrm{B}$ component of hemolysin BL from Bacillus cereus. Journal of Bacteriology, 175, 6760-6766.

Helmy, Z. A., El-Bakey, A., \& Mohamed, E. I. (1984). Occurrence of Bacillus cereus in milk and milk products in Egypt. Zentralblatt fur Microbiologie, 139, 129-133.

Höfte, H., \& Whiteley, H. R. (1989). Insecticidal crystal proteins of Bacillus thuringiensis. Microbiology and Molecular Biology Reviews, 53, 242-255.

Hsieh, Y. M., Sheu, S. J., Chen, Y. L., \& Tsen, H. Y. (1999). Enterotoxigenic profiles and polymerase chain reaction detection of Bacillus cereus group cells and B. Cereus strains from foods and food-borne outbreaks. Journal of Applied Microbiology, 87, 481-490.

Iurlina, M. O., Saiz, A. M., Fuselli, S. R., \& Fritz, R. (2006). Prevalence of Bacillus spp. in different food products collected in Argentina. LWT-Food Science and Technology, $39,105-110$.

Jensen, G. B., Larsen, P., Jacobsen, B. L., Madsen, B., Wilcks, A., Smidt, L., et al. (2002a). Isolation and characterization of Bacillus cereus-like bacteria from faecal samples from greenhouse workers who are using Bacillus thuringiensis-based insecticides. International Archives of Occupational and Environmental Health, 75, 191-196.

Jensen, G. B., Larsen, P., Jacobsen, B. L., Madsen, B., Smidt, L., \& Andrup, L. (2002b). Bacillus thuringiensis in fecal samples from greenhouse workers after exposure to B. Thuringiensis-based pesticides. Applied and Environmental Microbiology, 68, 4900-4905.

Johnston, D. W., \& Bruce, J. (1982). Incidence of thermoduric psychrotrophs in milk in the West of Scotland. Journal of Applied Bacteriology, 52, 333-337.

Kobayashi, T., Hatada, Y., Higaki, N., Lusterio, D. D., Ozawa, T., Koike, K., et al. (1999) Enzymatic properties and deduced amino acid sequence of a high alkaline pectate lipase from alkaliphilic Bacillus isolate. Biochimica et Biophysica Acta 1427, 145-154.

Kumar, T. D., Muralli, H. S., \& Batra, H. V. (2008). Construction of a non toxic chimeric protein $\left(\mathrm{L}_{1}-\mathrm{L}_{2}-\mathrm{B}\right)$ of Haemolysin $\mathrm{Bl}$ from Bacillus cereus and its application in HBL toxin detection. Journal of Microbiological Methods. doi:10.1016/j.mimet.2008.07.020.

Lund, T., Debuyser, M. L., \& Granum, P. E. (2000). A new cytotoxin from Bacillus cereus that may cause necrotic enteritis. Molecular Microbiology, 38, 254-261.

Mäntynen, V., \& Lindström, K. (1998). A rapid PCR-based DNA test for enterotoxic Bacillus cereus. Applied and Environmental Microbiology, 64, 1634-1639.

Meer, R. R., Baker, J., Bodyfelt, F. W., \& Griffiths, M. W. (1991). Psychrotrophic Bacillus spp. in fluid milk products. Journal of Food Protection, 54, 969-979.

Moravek, M., Wegscheider, M., Schulz, A., Dietrich, R., Bürk, C., \& Märttlbauer, E. (2004). Colony immunoblot assay for the detection of hemolysin BL enterotoxin producing Bacillus cereus. FEMS Microbiology Letters, 238, 107-113.

Ohba, M., \& Aratake, Y. (1994). Comparative study of the frequency and flagellar serotype flora of Bacillus thuringiensis in soils and silkworm-breeding environments. Journal of Applied Bacteriology, 76, 203-209.

Ouoba, L. I., Thorsen, L., \& Varnam, A. H. (2008). Enterotoxins and emetic toxins production by Bacillus cereus and other species of Bacillus isolated from Soumbala and Bikalga, African alkaline fermented food condiments. International Journal of Food Microbiology, 124, 224-230.

Öner, Z., Karahan, A. G., \& Aloğlu, H. (2006). Changes in the microbiological and chemical characteristics of an artisanal Turkish white cheese during ripening. LWT-Food Science and Technology, 39, 449-454.

Perani, M., Bishop, A. H., \& Vaid, A. (1998). Prevalence of $\beta$-exotoxin, diarrhoeal toxin and specific $\delta$-endotoxin in natural isolates of Bacillus thuringiensis. FEMS Microbiology Letters, 160, 55-60.

Phillips, J. D., \& Griffiths, M. W. (1986). Factors contributing to the seasonal variation of Bacillus spp. in pasteurized dairy products. Journal of Applied Bacteriology, 61, 275-285.

Priest, G. F., Goodfellow, M., \& Todd, C. A. (1988). A numerical classification of the genus Bacillus. Journal of General Microbiology, 134, 1847-1882.

Rosenquist, H., Smidt, L., Andersen, S. R., Jensen, G. B., \& Wilcks, A. (2005). Occurrence and significance of Bacillus cereus and Bacillus thuringiensis in readyto-eat food. FEMS Microbiology Letters, 250, 129-136.

Rukure, G., \& Bester, B. H. (2001). Survival and growth of Bacillus cereus during Gouda cheese manufacturing. Food Control, 12, 31-36.

Ryan, P. A., Macmillan, J. D., \& Zilinskas, B. A. (1997). Molecular cloning and characterization of the genes encoding the L1 and L2 components of hemolysin BL from Bacillus cereus. Journal of Bacteriology, 179, 2551-2556.

Schoeni, J. L., \& Wong, A. C. L. (1999). Heterogenity observed in the components of Haemolysin BL, an enterotoxin produced by Bacillus cereus. International Journal of Food Microbiology, 53, 159-167.

Svensson, B., Monthán, A., Guinebretiére, M-H., Broussolle, V., Nguyen-The, C., \& Christiansson, A. (2007). Toxin production potential and the detection of toxin genes among strains of the Bacillus cereus group isolated along the dairy production chain. International Dairy Journal, 17, 1201-1208.

te Giffel, M. C., Beumer, R. R., Leijendekkers, S., \& Rombouts, F. M. (1996). Incidence of Bacillus cereus and Bacillus subtilis in foods in the Netherlands. Food Microbiology, 13, 53-58.

te Giffel, M. C., Beumer, R. R., Granum, P. E., \& Rombouts, F. M. (1997). Isolation and characterization of Bacillus cereus from pasteurised milk in household refrigerators in the Netherlands. International Journal of Food Microbiology, 34 307-318.

Tham, W. A., Hadju, L. J., \& Danielsson-Tham, M. L. V. (1990). Bacteriological quality of on-farm manufactured goat cheese. Epidemiology and Infection, 104, 87-100.

Torkar, K. G., \& Matijašić, B. B. (2003). Partial characterisation of bacteriocins produced by Bacillus cereus isolates from milk and milk products. Food Technology and Biotechnology, 41, 121-129.

Travers, R. S., Martin, P. A. W., \& Reichelderfer, C. F. (1987). Selective process for efficient isolation of soil Bacillus spp.. Applied and Environmental Microbiology, 53, 1263-1266.

Tsen, H. Y., Chen, M. L., Hsieh, Y. M., Sheu, S. J., \& Chen, Y. L. (2000). Bacillus cereus group strains, their hemolysin BL activity, and their detection in foods using a 16S RNA and hemolysin BL gene-targeted multiplex polymerase chain reaction system. Journal of Food Protection, 63, 1496-1502.

Zahner, V., Cabral, D. A., Régua-Mangia, A. H., Rabinovitch, L., Moreau, G., \& McIntosh, D. (2005). Distribution of genes encoding putative virulence factors and fragment length polymorphisms in the vrrA gene among Brazilian isolates of Bacillus cereus and Bacillus thuringiensis. Applied and Environmental Microbiology, 71, 8107-8114. 